been placed on imports. To meet the situation it was, therefore, determined to issue, as rapidly as possible, a series of memoirs on special subjects. For this purpose the Geological Survey was well equipped. In the course of their normal work, that of surveying the country first on the one-inch and then on the six-inch scale, they had acquired and recorded in the maps and memoirs relating to special districts a large amount of information as to the mineral resources of the country. But this information, except in the case of a few substances, such as oil-shales and china-clays, was not readily available to those interested in particular minerals. The preparation of these memoirs, therefore, consisted in collecting the information which is scattered through the various local publications extending over a period of sixty or seventy years, and in supplementing this, so far as time would permit, by special investigations in districts where the minerals in question occur.

Three memoirs have now been published. The first deals with ores of tungsten and manganese, the second with barytes and witherite, and the third with gypsum and anhydrite, celestine and strontianite. The same general plan is followed in each case. The introductory chapters deal briefly with the composition, properties, and uses of the substance, with the rise and progress of the industry in this country, and with statistics of production. Then follows the most valuable part from the practical point of view, namely, that which deals with the mines or quarries from which the minerals are or have been produced, and also with occurrences which have not yet been commercially exploited. Take as an illustration of the method of treatment the case of tungsten. Its principal ore, wolfram, usually occurs in association with cassiterite, from which it is not easily separated. Previous to the discovery, in comparatively recent times, of the use of the metal in the manufacture of high-speed steel and filaments for electric lamps, wolfram was regarded as a nuisance by tin-miners. It was thrown away on the dumps, and caused the abandonment of several Cornish mines, some of which have been reopened in recent years in consequence of improved methods of dressing the mixed ore and of the value of what was formerly a waste product.

In the special part of this memoir the mines, whether abandoned or working, in which ores of tungsten occur are individually described. In the case of each mine the locality is indicated, not only by name, but also by reference to the oneinch and six-inch maps and to latitude and longitude. When the name only of an old mine is given it is often extremely difficult to fix its precise locality, but by this method all difficulty is removed. In the case of abandoned mines the old records have been examined, and all available information is given as to the course of the lodes, their content in wolfram and other minerals, and their relation to the surrounding rocks. In the case of mines now being worked the information on these points has been brought up to date, and is, of course, much more complete. The position NO. 242 I, VOL. 97] of each mine in relation to roads and railways is given, and, when information is available, its condition as regards water. From the above statement it will be seen that the requirements of the practical man have been supplied so far as possible.

The three memoirs already published have been produced by the existing staff of the Geological Survey, notwithstanding the fact that several of its members are serving with the Army in various capacities. In view of the urgency and importance of this kind of work, some of which has direct reference to the war, we venture to ask whether it would not be advisable to increase the output by utilising the services of unofficial geologists?

We congratulate the Director and his staff on the excellence of these memoirs, and on the rapidity with which they have been brought out; and we hope that it will not be long before they are followed by others of a similar character.

\section{COLONEL SIR CHARLES WATSON, C.B., K.C.M.G., R.E.}

WE regret to record the death of Colonel Sir Charles Watson, in London on March ${ }_{5} 5$, at the age of seventy-one.

Sir Charles Watson was the son of William Watson, a well-known civil engineer of Dublin, and he distinguished himself in mathematics and modern languages at Trinity College. In 1863 he entered the Royal Military Academy, Woolwich, at the head of the list, and two years later was commissioned in the Royal Engineers. Interested in the scientific side of his profession, Watson took up submarine mining, which was then a new branch of military engineering, and was posted to the first submarine mining company in $187 \mathrm{I}$. About this time, also, he interested himself in ballooning, though not until later was this branch of military science actively developed.

While at Chatham he came under the notice of General Gordon, who invited him and Lieut. Chippendale, R.E., to accompany him to the Sudan. They travelled with General Gordon to Khartoum and thence up the Nile to Gondokoro. Watson carried out such a survey of the White Nile and the Bahr el Tebel as was possible from the steamer, and his work was a great advance on the earlier maps of the river. From i 874 up to I9oo his work was the basis of all maps of this part of the Nile's course, and when the opportunity arose for a new survey of the Bahr el Tebel, Watson's observations, made twentyseven years before, were of great value in determining the permanence of the river channel and the alterations which had taken place in its branches. He also made careful meteorological observations in the marsh region, and measured a discharge of the Sobat River at its junction with the White Nile. Invalided to England in I 875 he was again in Egypt in I882, but both then, and again later when in the Egyptian Army, military duties prevented him from devoting much of his time to scientific work. 
After his retirement from the Army, in 1902, he organised the British Section of the St. Louis International Exhibition in 1904. His interest in Egypt and the Sudan never waned, and in 1912 the latter was the subject of an address which he gave as president of the Geography Section of the British Association. His interest in the East, and in the scientific study of it, led to his accepting the presidency of the Palestine Exploration Fund in succession to his friend and brotherofficer, Sir Charles Wilson, and in this position he not only supported the prosecution of scientific archæology, but also advanced our knowledge of the topography of southern Palestine.

Interested in metrology, he championed, in a work on the subject, the cause of British weights and measures as preferable to those of the metric system. His inquiries into the various standards of length led him into an interesting bye-path of history, and it was only last week that we published a paper by him wherein he showed the close connection of our present standards of length and area with the old Egyptian and Babylonian measures.

\section{NOTES.}

$\mathrm{ON}_{N}$ account of the restrictions imposed by the Government on the importation of wood-pulp and other materials used in paper manufacture, the supply of paper has been compulsorily reduced. In common with other periodicals, we are, therefore, under the necessity of reducing the size of NATURE; and we ask the indulgence of our readers for the cultailments which must be made while the limitations of papersupply exist. It is particularly desirable that all contributors should confine themselves to essentials, points of prime importance, in order that our record of scientific work and events may still be as extensive as possible, though it must necessarily be less detailed. We trust that the present conditions are only temporary, and need scarcely say that immediately the normal supply of paper is available we shall revert to the usual number of columns.

THE London Gazette of March I3 notifies the appointment of and Lieut. G. I. Taylor, R.F.C., to the temporary rank of Major in the Royal Flying Corps, while performing the duties of professor of meteorology. Major Taylor is a fellow of Trinity College, Cambridge, to whom the Adams prize was recently awarded. He is the author of the valuable report on meteorology in the voyage of the Scotia, undertaken for the Board of Trade. Up to the outbreak of war he held the Schuster readership of the Meteorological Office at the University of Cambridge. His predecessor in that appointment was Mr. E. Gold, now Commandant of the Meteorological Section, R.E., who was mentioned in Lord French's despatches, and has been nominated for the D.S.O. The professorship of meteorology to which Major Taylor is appointed is a new establishment, for which the Meteorological Office is responsible, for instruction and special researches in the structure of the atmosphere in the interest of the Royal Flying Corps.

We regret to see the announcement of the death, on March I6, of Lady Kelvin: she survived by nine years her husband, who died on December 17, 1907. Lady Kelvin (née Frances Anna Blandy) was a daughter of the late Charles R. Blandy, one of the principal resi- dents of Madeira. Lord Kelvin, then Sir William Thomson, first met her during one of the submarine cable-laying expeditions, in June, 1873 . The acquaintance then made ripened into more than friendship, and a year later Sir William sailed to Madeira in his yacht, the Lalla Rookh, to claim Miss Blandy as his wife. They were married on June 24, 1874, and sailed back in the yacht. Early in August Lady Thomson was welcomed into the circle of family relations and university colleagues at Glasgow, and directed his household with dignity and grace. She became the inseparable companion of his after life, and accompanied him not only in his many summer voyages on his yacht, and on two trips to the United States, and on visits to foreign academies, but became a familiar figure at British Association meetings and other scientific gatherings. Soon after their marriage Sir William and Lady Thomson busied themselves over the building of his country house, "Netherhall," near Largs, in Ayrshire, the scene in after years of many family reunions and of extended hospitalities. It was to this house that Lord Kelvin withdrew when he retired in I899 from his professorship at Glasgow; it was there that he died, and there also Lady Kelvin has died. Lady Kelvin from about twenty years ago had suffered from rheumatic troubles, and was accustomed to pay an annual visit to Aix-les-Bains for a course of treatment. It was during her return from that resort in September, 1907, that she was struck down by a severe paralysis, from which she had not recovered when Lord Kelvin died, and which left her infirm for the rest of her life, which she spent between the home at Netherhall and the residence in Eaton Place, Belgravia, which Lord Kelvin had taken after his elevation to the peerage in I892. Lady Kelvin was fond of society, and played the part of hostess with stately dignity. She was president of the West of Scotland Women's Unionist Association, but otherwise took no considerable part in politics. The assiduous care and thought with which she devoted herself to Lord Kelvin during his declining years are known to all.

DR. D. H. ScotT, F.R.S., has been elected a foreign member of the Royal Swedish Academy of Sciences, in succession to the late Count Solms-Laubach.

THE anniverary meeting of the Chemical Society will be held on Thursday, March 30, when Dr. Alexander Scott will deliver his presidential address, entitled "Our Seventy-fifth Anniversary."

The Right Rev. Dr. J. H. Bernard, Archbishop of Dublin, has been elected president of the Royal Irish Academy in succession to Prof. J. P. Mahaffy, Provost of Trinity College, Dublin.

The Morning Post of March 20 announces that Thursday last, being the seventieth birthday of the distinguished Swedish mathematician, Prof. M. G. Mittag-Leffler, he and his wife bequeathed their entire fortune to the foundation of a new International Institute for pure mathematics.

ThE Secretary of the War Office announces that Surgeon-General W. Babtie, V.C., has been appointed to assist Surgeon-General Sir A. Keogh, DirectorGeneral Army Medical Services, especially in the work of supervision of invaliding and all questions connected with the physical fitness of the troops at home.

WE learn from the American Journal of Science that Prof. J. C. Moberg, of the University of Lund, Sweden, the distinguished palæontologist and stratigrapher, died on December 30, 1915, at the age of sixty-one years. His scientific work related in the main to the older Palæozoic formations of Sweden.

No. 242 I, VOL. 97] 